\title{
Influence of watershed's anthropogenic activities on fish nitrogen and carbon stable isotope ratios in nine French lakes
}

\author{
A-L. Borderelle ${ }^{(1)}$, D. Gerdeaux ${ }^{(2)}$, P. Giraudoux ${ }^{(1)}$ and V. Verneaux ${ }^{(1)}$ \\ Received July 17, 2008 / Reçu le 17 juillet 2008 \\ Revised August 20, 2008 / Révisé le 20 août 2008 \\ Accepted February 18, 2009 / Accepté le 18 février 2009
}

\section{ABSTRACT}

Key-words: $\quad$ The relationships between fish community $\delta^{15} \mathrm{~N}$ and $\delta^{13} \mathrm{C}$ values and land $\delta^{15} \mathrm{~N}$, fish community, anthropogenic activity, watershed, buffer zone, lakes use in watersheds and in buffer zones of nine French lakes were studied. The results showed inter-lakes variability of mean $\delta^{15} \mathrm{~N}$ and $\delta^{13} \mathrm{C}$ values for different fish species. The study of correlations between fish $\delta^{15} \mathrm{~N}$ and $\delta^{13} \mathrm{C}$ values and the proportions from different land use categories in watersheds showed a land use effect on fish $\delta^{15} \mathrm{~N}$ values but not on $\delta^{13} \mathrm{C}$ values. The results underlined the great impact of manure spreading on grasslands as a nitrate source in our lakes. Nevertheless, the best correlations between fish $\delta^{15} \mathrm{~N}$ values and land use were obtained when the entire fish community (i.e. the whole fish community mean $\delta^{15} \mathrm{~N}$ values in each lake) and all anthropogenic activities (residential lands, camp sites and grasslands for our systems) were considered in either watersheds or in buffer zones. Thus, for our sites, the fish $\delta^{15} \mathrm{~N}$ values are useful to evaluate nitrogen inputs from human and animal wastes at the watershedscale as well as at the buffer zone-scale. The absence of land use effect on the fish community $\delta^{13} \mathrm{C}$ values could be at least partly explained by the small size of these lakes in which it has been shown that consumers, namely macroinvertebrates, have $\delta^{13} \mathrm{C}$ values largely influenced by organic matter recycling activity.

\section{RÉSUMÉ}

Influence des activités humaines des bassins versants sur les ratios d'isotopes stables d'azote et de carbone des poissons dans neuf lacs français
Mots-clés :
Les relations entre les valeurs de $\delta^{15} \mathrm{~N}$ et $\delta^{13} \mathrm{C}$ des communautés pisciaires, l'oc-
$\delta^{15} N$, cupation des bassins versants et des zones tampon de neuf lacs français ont été communautés étudiées. Les résultats montrent une variablilité inter-lac des valeurs moyennes de $\delta^{15} \mathrm{~N}$ et $\delta^{13} \mathrm{C}$ pour les différentes espèces. L'étude des relations entre les valeurs piscicoles, activités humaines, bassin versant, zones tampon, isotopiques des poissons et les proportions des différentes catégories d'usage des bassins versants montre une corrélation entre l'occupation des sols et les va- leurs de $\delta^{15} \mathrm{~N}$ des poissons alors qu'aucune corrélation n'apparaît si l'on considère les valeurs de $\delta^{13} \mathrm{C}$. Les résultats obtenus mettent en évidence l'impact important lacs

(1) University of Franche-Comté, Department of Chrono-environment, UMR UFC/CNRS 6249 USC INRA, place Leclerc, 25030 Besançon cedex, France

(2) INRA, UMR CARRTEL, Avenue de Corzent, BP 511, 74203 Thonon-les-Bains, France, daniel.gerdeaux@thonon.inra.fr 
de l'utilisation des lisiers sur prairies comme source de nitrate dans ces lacs. Les meilleures corrélations entre les valeurs de $\delta^{15} \mathrm{~N}$ des poissons et l'occupation de l'espace sont obtenues quand la communauté de poissons dans son ensemble (c'est-à-dire les valeurs moyennes de $\delta^{15} \mathrm{~N}$ pour toutes les espèces dans chaque lac) et toutes les activités anthropiques (zones d'habitation, camping et prairies) sont prises en compte aussi bien au niveau du bassin versant que de la zone tampon. Pour les lacs étudiés, les valeurs de $\delta^{15} \mathrm{~N}$ des poissons permettent d'évaluer l'impact des apports d'azote dus aux déchets humains et animaux, aussi bien au niveau du bassin versant que de la zone tampon. L'absence de corrélation entre l'occupation des sols et les signatures en carbone des poissons peut être expliquée, au moins partiellement, par la petite taille de ces lacs dans lesquels il a été montré que les consommateurs, dont les macroinvertébrés, ont des valeurs de $\delta^{13} \mathrm{C}$ largement influencées par le recyclage interne de la matière organique.

\section{INTRODUCTION}

For the last twenty-five years, stable isotope analysis has been used to study food webs and energy flows in both terrestrial and aquatic ecosystems (Gu et al., 1997; Ponsard and Arditi, 2000; Ehleringer et al., 2002). Among the stable isotopes, stable nitrogen isotope ratios $\left(\delta^{15} \mathrm{~N}\right)$ are useful for defining the structure of the food web and, especially the trophic position of consumers (Vander Zanden et al., 1997; Post et al., 2000) whereas stable carbon isotopes are used to track the carbon source from its origin at the base of the food web (Schlinder et al., 1997; Post et al., 2000). In fact, $\delta^{15} \mathrm{~N}$ and $\delta^{13} \mathrm{C}$ values are passed on from the food source to consumers with characteristic enrichment. $\delta^{13} \mathrm{C}$ changes little from prey to predator with mean trophic fractionation of $+0.39 \%$ o \pm 1.3 in aquatic food webs (Post, 2002). In case of $\delta^{15} \mathrm{~N}$, consumers are enriched compared to the food, with a typical fractionation of $+3.4 \% \pm 1.1$ in aquatic food webs (Post, 2002). Therefore, isotope signatures of primary and secondary consumers scale to isotopic signatures of primary producers (Lajtha and Marshall, 1994). Variation in primary producer isotope ratios is integrated in higher level consumers.

The available dissolved nitrogen sources (DIN) for primary producers are varied (atmospheric source, ammonium, $\mathrm{NO}_{3}^{-}$) and, different processes may be involved in establishing the $\delta^{15} \mathrm{~N}$ values of DIN: microbial nitrification, denitrification and anthropogenic contributions (Cabana and Rasmussen, 1996; Cole et al., 2004). Concerning this last point, several groundwater studies have used stable isotope signatures of naturally abundant $\mathrm{NO}_{3}{ }^{-}$to identify the major $\mathrm{N}$ sources (wastewater, fertilizer, and atmospheric deposition) to aquifers (Kreitler et al., 1978; Kreitler, 1979; Aravena et al., 1993). These studies have shown that groundwater influenced only by atmospheric deposition have $\delta^{15} \mathrm{~N}$ values for $\mathrm{NO}_{3}{ }^{-}$ranging from +2 to $+8 \%$, whereas $\mathrm{NO}_{3}^{-}$derived from human and animal wastes is more enriched in ${ }^{15} \mathrm{~N}(+10$ to $+20 \%$ o) and nitrate from synthetic fertilizers is more depleted in ${ }^{15} \mathrm{~N}$ ( -3 to $+3 \%$ o) (Gormly and Spalding, 1979; Macko and Ostrom, 1994). Thus, $N$ contribution from different sources can produce some variation in the $\delta^{15} \mathrm{~N}$ signature of primary producers at the base of the food chain $\left(\delta^{15} \mathrm{~N}\right.$ baseline) which is passed on to the consumer species. Cabana and Rasmussen (1996), McClelland et al. (1997), Lake et al. (2001) and Cole et al. (2004) have emphasized the influence of anthropogenic activities (wastewater in particular) in watersheds or in buffer zones on the $\delta^{15} \mathrm{~N}$ values of primary producers and consumers in estuarine and in small freshwater systems.

About $\delta^{13} \mathrm{C}$ values, among factors that could affect autochthonous primary producers $\delta^{13} \mathrm{C}$ $\left(\delta^{13} \mathrm{C}\right.$ baseline), and consequently consumers $\delta^{13} \mathrm{C}$, the major one is the dissolved inorganic carbon (DIC) $\delta^{13} \mathrm{C}$ value. This latter depends on its origin: dissolved atmospheric $\mathrm{CO}_{2}$ $\left(\delta^{13} \mathrm{C}=0 \%\right.$, Peterson and Fry, 1987), dissolved carbon from the substratum and dissolved $\mathrm{CO}_{2}$ from respiration as a result of organic matter mineralization. It has been shown that heterotrophic organic matter recycling activity may lead to a decrease in DIC $\delta^{13} \mathrm{C}$ values (France, 2000) whereas an increase in lake primary production may lead, in great lakes, 
to an increase in DIC $\delta^{13} \mathrm{C}$ values and consecutively in that of the whole lake food web (Gu et al., 1996; Schindler et al., 1997). The proportion of carbon derived from the dissolution of atmospheric $\mathrm{CO}_{2}$ and from respired $\mathrm{CO}_{2}$ depends on the lake area and the nutrient inputs (Schlindler and Scheuerell, 2002). Therefore, nutrient inputs from the watershed or the buffer zone may modify DIC $\delta^{13} \mathrm{C}$ values and consecutively $\delta^{13} \mathrm{C}$ baseline values. In addition, benthic and pelagic primary producers discriminate differently against ${ }^{13} \mathrm{C}$ so that, with the same dissolved atmospheric carbon source, the benthic producers show highest $\delta^{13} \mathrm{C}$ values (-27\%o, Sierszen et al., 2003) than the pelagic one (-31\%o, Sierszen et al., op.cit.).

Fish nitrogen and carbon isotopic ratios may then reflect change in $\delta^{13} \mathrm{C}$ and $\delta^{15} \mathrm{~N}$ baselines following variations in DIC and DIN isotopic ratios, or change in fish diet e.g. trophic shift from a benthic to a pelagic food source following change in nutrient inputs (Vadeboncœur et al., 2001).

The first aim of this study was to test the relationships between $\delta^{15} \mathrm{~N}$ and $\delta^{13} \mathrm{C}$ values of fish and the land use in watersheds and in buffer zones, in nine French lakes. Secondly, the aim was to define, among studied systems, the major anthropogenic activity that influences fish $\delta^{15} \mathrm{~N}$ and $\delta^{13} \mathrm{C}$ values. In fact, anthropogenic nutrient inputs changed nitrogen and carbon availability and cycling, which are likely to increase ecosystem productivity, shift the balance between benthic and pelagic productivity, modify the food chain length, increase the carrying capacity of the system for fishes and influence the $\delta^{15} \mathrm{~N}$ and $\delta^{13} \mathrm{C}$ fish values.

\section{METHODS}

\section{> STUDY SITES}

Nine French lakes located in the Jura region of eastern France were studied: lakes Bonlieu, Chalain, Clairvaux, Ilay, Maclu, Narlay, Remoray, Les Rousses and Saint-Point. Their morphological characteristics greatly differed as well as their altitude but, their watersheds shared the same calcareous geological substratum (Table I).

\section{$>$ FISH SAMPLING}

Fish were collected, from 2002 to 2005 , with gillnets of varying mesh (25 mm to $60 \mathrm{~mm} \mathrm{knot}$ to knot), set in benthic and pelagic zones in order to sample all species. Only adults of each species were selected for stable isotope analysis. A minimum of three fishes per species were selected for stable isotope analysis. For some sites (lakes Bonlieu, Ilay and Maclu), only one individual for one fish species was available and its $\delta^{15} \mathrm{~N}$ and $\delta^{13} \mathrm{C}$ values were used (i.e. pike Esox lucius L. or/and tench Tinca tinca L.). For the other sites and species, the each fish species mean $\delta^{15} \mathrm{~N}$ and $\delta^{13} \mathrm{C}$ values for each lake were considered and, the mean of these means was considered to define the whole fish community mean $\delta^{15} \mathrm{~N}$ and $\delta^{13} \mathrm{C}$ values.

\section{> CARBON AND NITROGEN STABLE ISOTOPE RATIOS}

One milligram samples of dried and finely ground dorsal muscle of each organism were weighted in $6 \times 4 \mathrm{~mm}$ tin cups for CF-IRMS analysis using a Europa Scientific ANCA-NT 2020 Stable Isotope Analyser with a NCA-NT Solid/Liquid Preparation Module (PDZ Europe Ltd., Crewe, UK). The analytical precision (SD), estimated from five standards analysed along with the samples, was $0.2 \%$. Working standards for analytical precision consisted of 1.0 or $1.5 \mathrm{mg}$ leucine prepared by freeze drying $50 \mathrm{~mL}$ of a $20 \mathrm{mg} \cdot \mathrm{mL}^{-1}$ stock solution in the tin cups, and calibrated against "Europa flour" and IAEA standards N1 and N2. All stable isotope values are expressed in the $\delta$ notation, in units of parts per thousand (\%o) where: $\delta=$ $\left[\left(R_{\text {sample }}-R_{\text {standard }}\right) / R_{\text {standard }}\right] \times 1000$. For $\delta^{15} \mathrm{~N}$ values, $R={ }^{15} \mathrm{~N} /{ }^{14} \mathrm{~N}$ and atmospheric nitrogen is standard material and for $\delta^{13} \mathrm{C}$ values, $\mathrm{R}={ }^{13} \mathrm{C} /{ }^{12} \mathrm{C}$ and standard material is Pee Dee Belemnite. 


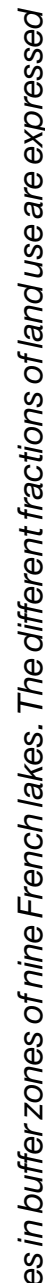

乌

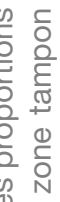

(1)

के



วิ

สิ

ठ

c

언

(요

茎过

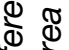

$\frac{\pi}{\frac{\pi}{\pi}}$

$\stackrel{2}{\frac{1}{0}}$

का

के

仓

ญ ญ

एे के

(1)

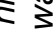

ठ

\&

ঠे

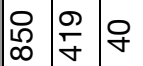

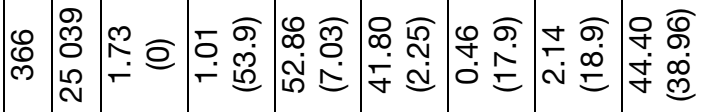

落

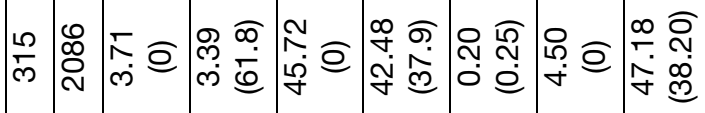

()

递饮

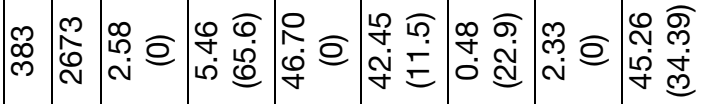

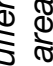

$\frac{\sqrt{2}}{\sqrt[2]{2}}$

क 유

(1)

व)

票

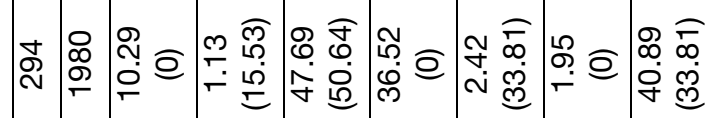

$\stackrel{n}{3}$

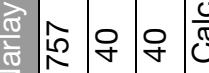

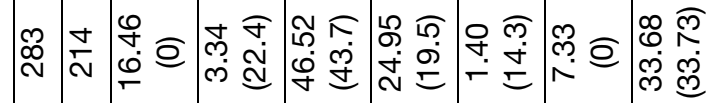

บิ

잉

ఫొ

용

ㅇำ

สิ

ㅇำ

(⿻)

ठิ

के

के ญ

T.

3

¿

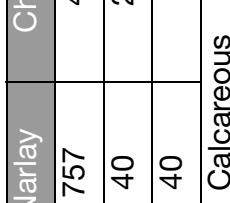

蛋

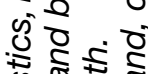

के

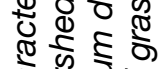

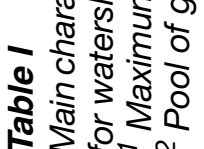

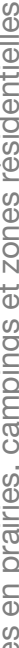

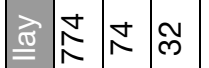

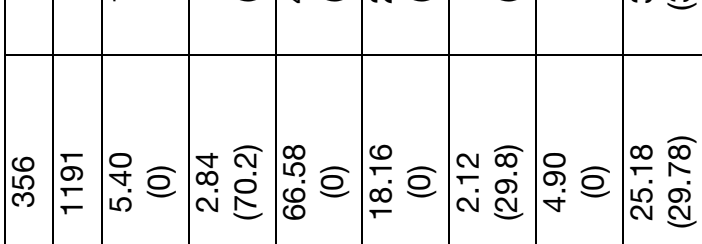

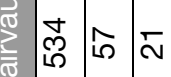

온

$\frac{1}{9} \frac{0}{4}$

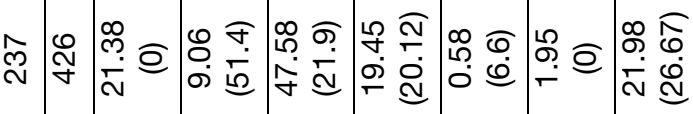

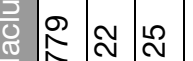

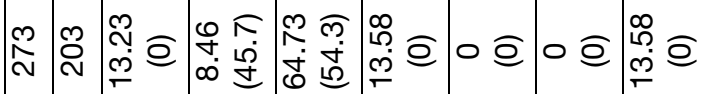

잉

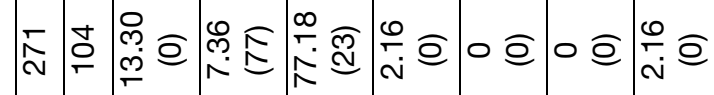

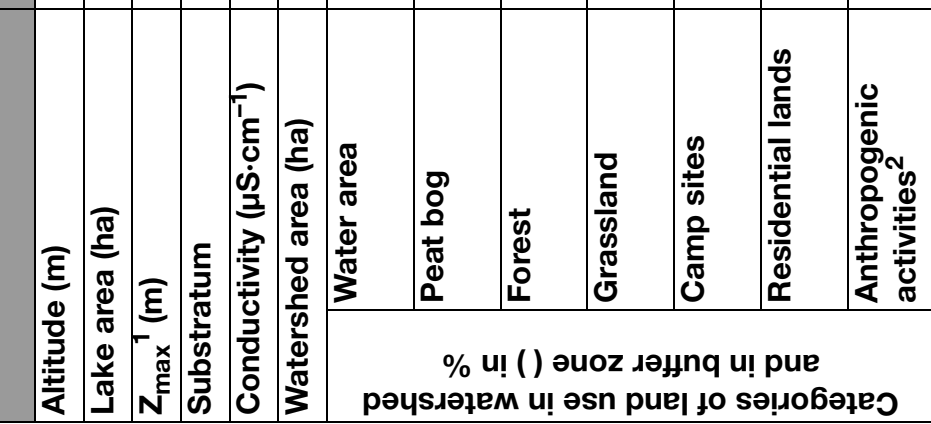




\section{$>$ WATERSHED DESCRIPTION}

In each watershed, the different categories of land use (water, grassland, residential land, camp sites, forest and peat bog) were charted from NGI (National Geographical Institute) $1 / 25000$ maps and modified by visit of the sites. Agricultural practices were examined. The area of each land use category was calculated and converted as a percentage of the total area of each watershed. The watersheds of the nine studied lakes are rural and the agricultural practice was dairy production. This practice was accompanied by substantial manure spreading on grassland. Three land use categories can form potential inputs of human and livestock waste nitrogen (grassland, residential land, camp sites) so that they were pooled together to evaluate the global anthropogenic activity.

Furthermore, buffer zones surrounding each lake, defined as a ground strip of $150 \mathrm{~m} \pm 50$ according to topography, were studied: as for the watershed, the different categories of land use were charted from NGI maps then field work. Their area were calculated, then these latter were converted as a percentage of the total area of each buffer zone The global anthropogenic activity was evaluated by pooling even categories as for watersheds.

\section{> STATISTICAL ANALYSIS}

$\delta^{15} \mathrm{~N}$ and $\delta^{13} \mathrm{C}$ values were modelled according to the General Linear Model (GLM) as a linear function of fish species and land use variables of the form: $y=a_{1}+b x_{2}+c x_{3}+d x_{4}+$ $e x_{5}+f x_{6}+g x_{7}+\varepsilon$ where $y$ is the response variable $\left(\delta^{15} \mathrm{~N}\right.$ or $\left.\delta^{13} \mathrm{C}\right), x_{1}$ is a factor (each level being fish species), $x_{2}$ grassland area, $x_{3}$ residential land, $x_{4}$ forest area, $x_{5}$ water area, $x_{6}$ camp sites, $x_{7}$ peat bog area and $\varepsilon$ the residuals. A random effect was added to account for non independence of each measure at each lake. Residuals where examined and outliers and variance heteroscedasticity checked. Under the null hypothesis $\left(\mathrm{H}_{0}\right)$ of each model parameters equal to zero, the significance of parameters was then checked by analysis of variance $\left(\mathrm{H}_{0}\right.$ was rejected at a 0.05 probability). Non significant variables were thus removed sequentially in order to obtain a final model. A fish size effect was also added in the $\delta^{15} \mathrm{~N}$ final model but no significant size effect has been observed (ANOVA, DF $=352, P=0.14$ ).

Several kinds of models were examined changing the way land use variables were expressed. On the whole watershed, and on the buffer zone, land use variables were expressed (1) in hectares in order to take the size of watersheds or buffer zones into account, (2) in percentage in order to take the proportion of each land use component into account independently of watershed or buffer zone sizes.

Computing and graphical displays were performed using R 2.4.1 and the package nlme (R Development Core Team, 2006).

\section{RESULTS}

Six species of fish were caught. Species mean $\delta^{15} \mathrm{~N}$ values ranged from $3.6 \%$ for roach in Lake Bonlieu to $13.2 \%$ for pike in Lake Chalain and $\delta^{13} \mathrm{C}$ values ranged from $-36.7 \%$ in Lake Remoray for whitefish to $-27.6 \%$ for rudd in Lake Bonlieu (Table II, Figures 1 and 2). The largest range for species mean $\delta^{15} \mathrm{~N}$ and $\delta^{13} \mathrm{C}$ values in one lake is in Lake Chalain with a range from $8.0 \%$ o for rudd to $13.2 \%$ for pike for $\delta^{15} \mathrm{~N}$ and a range from $-26.6 \%$ o for rudd to $-35.9 \%$ for whitefish for $\delta^{13} \mathrm{C}$.

The fish $\delta^{15} \mathrm{~N}$ values were statistically different among species for each lake (Kruskal-Wallis, $n>36, P<0.0358$ ) except for Lake Les Rousses (Kruskal-Wallis, $n=21, P=0.0943$ ). Perch and/or whitefish $\delta^{15} \mathrm{~N}$ could be statistically separated from the other species (Scheffer's test) and pike was the most ${ }^{15} \mathrm{~N}$ enriched species except for Lake Saint-Point.

About fish $\delta^{13} \mathrm{C}$ values, statistical differences among species for each lake were also observed (Kruskal-Wallis, $n=21, P<0.0041$ ). Except for Lake Bonlieu, whitefish $\delta^{13} \mathrm{C}$ was lower than roach and/or rudd $\delta^{13} \mathrm{C}$ values (Scheffer's test). 


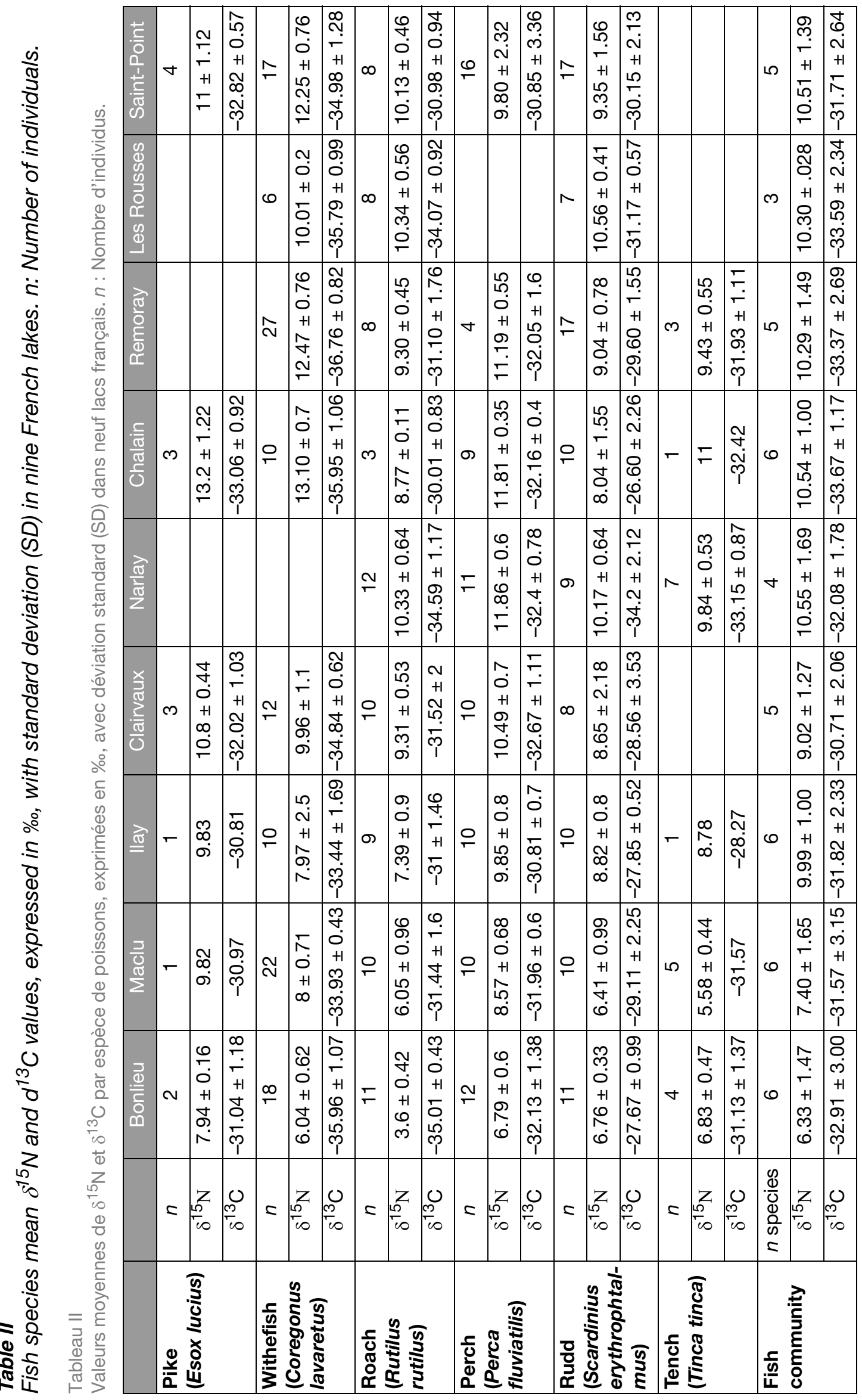



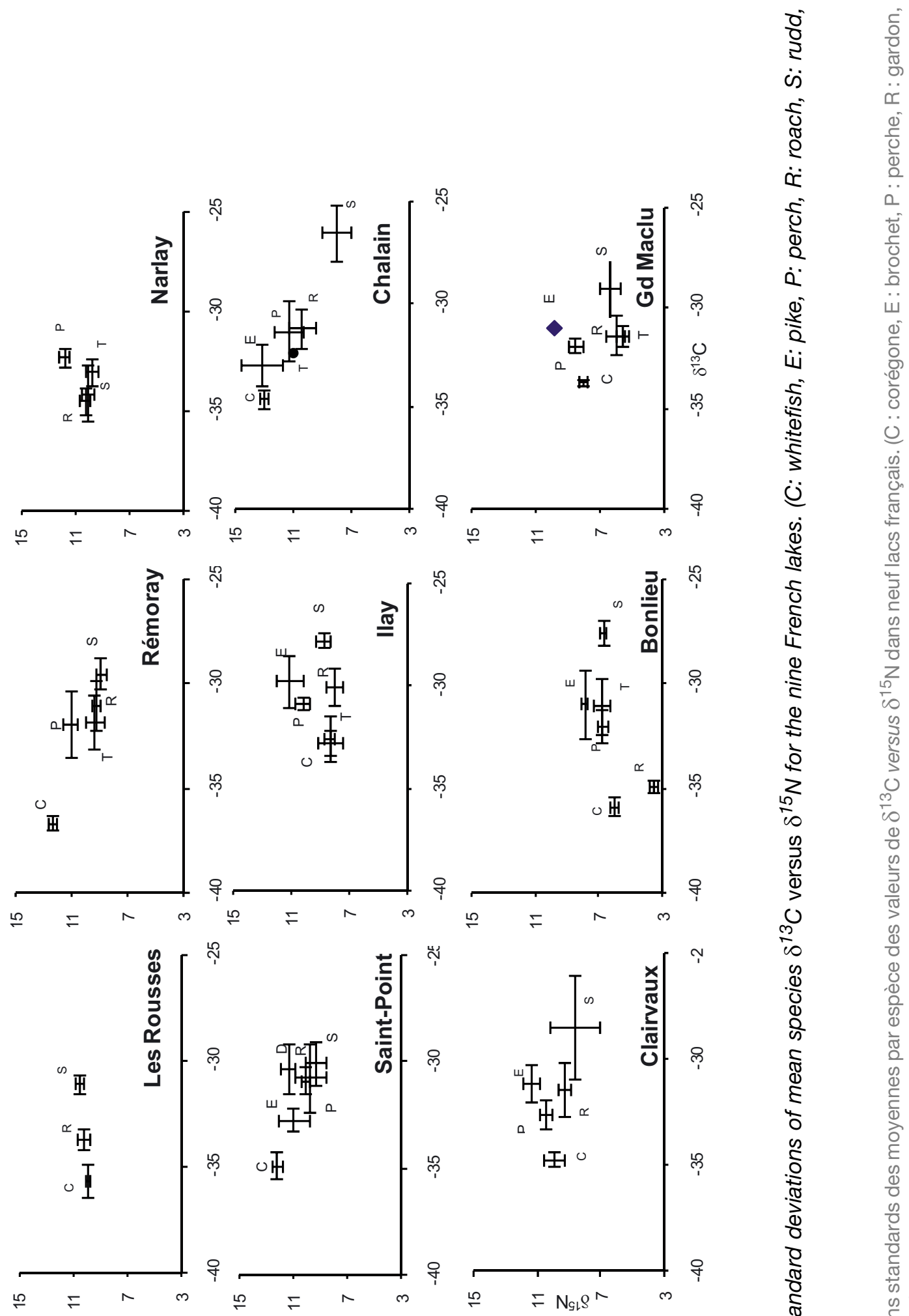

ปू

递

过

is

$\frac{\sqrt[3]{2}}{2}$

نे

禹

$\frac{\sqrt{0}}{\frac{d}{(1)}}$

L

$\stackrel{\Xi}{\Sigma}$

8

흐

$\frac{2}{10}$

O

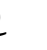

뜰

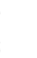



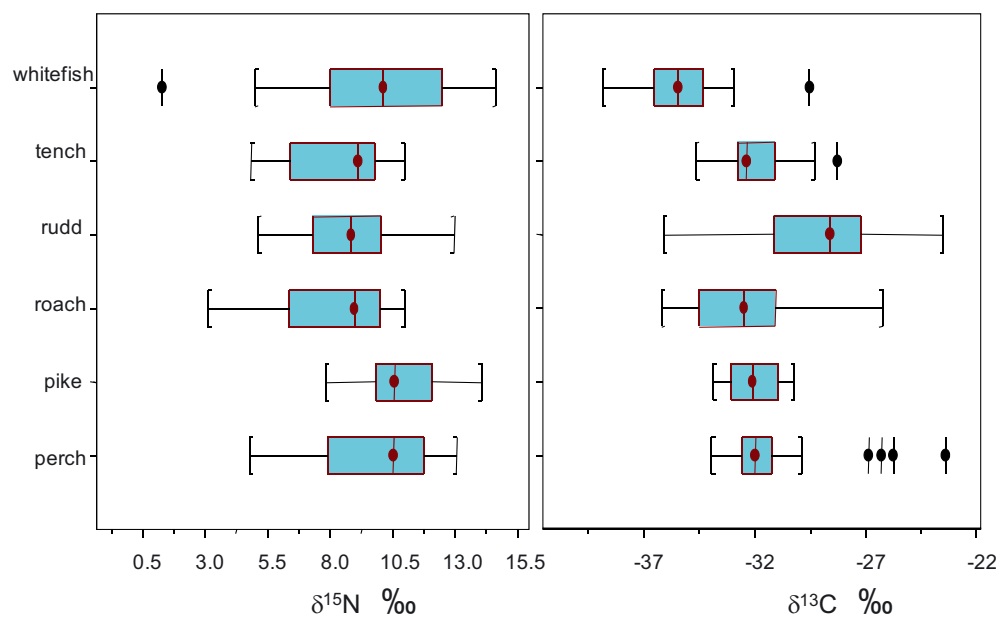

\section{Figure 2}

Box-plot of $\delta^{15} \mathrm{~N}$ and $\delta^{13} \mathrm{C}$ fish values in the nine French lakes.

Figure 2

Graphe box-plot des valeurs de $\delta^{15} \mathrm{~N}$ et $\delta^{13} \mathrm{C}$ des poissons dans neuf lacs français.

When species of each lake were ordered in increasing mean isotope values, it appears that the species positions greatly differed between lakes. Whitefish had the most variable position both for carbon and nitrogen but its mean $\delta^{13} \mathrm{C}$ value was the lowest compared to that of the other species. The overlaps between the ranges for species mean $\delta^{13} \mathrm{C}$ values were less than for $\delta^{15} \mathrm{~N}$ values (Fig. 2). Rudd and roach presented large ranges for both carbon and nitrogen ratios.

\section{> LAND USE IN WATERSHEDS AND IN BUFFER ZONES}

Considering their watershed land use, the lakes can be classified based on an increasing order of percentage of land affected by anthropogenic activity as followed: Bonlieu, Maclu, Ilay, Clairvaux, Narlay, Chalain, Saint-Point, Remoray and Les Rousses with $47.18 \%$ of land affected by anthropogenic activity (Table I).

The same classification was obtained when the percentage of the buffer zones affected by anthropogenic activity was considered, except for Lake Saint-Point. This lake had the buffer zone most affected by anthropogenic activity while its watershed was less affected than those of lakes Remoray and Les Rousses $(44.40 \%, 45.26 \%$ and $47.18 \%$ of land affected by anthropogenic activities respectively). For lakes Bonlieu and Maclu, the buffer zones were not affected by anthropogenic activity; land use consisted of wetland and forest cover.

\section{> RELATIONSHIPS BETWEEN LAND USE IN WATERSHEDS AND IN BUFFER ZONES AND FISH $\delta^{15} \mathrm{~N}$ AND $\delta^{13} \mathrm{C}$ VALUES}

The study of relationships between fish $\delta^{15} \mathrm{~N}$ or $\delta^{13} \mathrm{C}$ values and both fish species and area of land use categories in watershed expressed in hectares showed a fish species effect on the various $\delta^{15} \mathrm{~N}$ and $\delta^{13} \mathrm{C}$ values (ANOVA, $n=417$; for $\delta^{15} \mathrm{~N}$ values, DF $=403, P<0.0001$; for $\delta^{13} \mathrm{C}$ values, $\mathrm{DF}=335, P<0.0001$ ) but no effect of watershed size (ANOVA, $n=417$; for $\delta^{15} \mathrm{~N}$ values, $\mathrm{DF}=3, P=0.3601$; for $\delta^{13} \mathrm{C}$ values, $\mathrm{DF}=3, P=0.1667$ ). Pike was the most ${ }^{15} \mathrm{~N}$ enriched species in the studied lakes. About $\delta^{13} \mathrm{C}$ values, whitefish was the least ${ }^{13} \mathrm{C}$ enriched whereas the highest $\delta^{13} \mathrm{C}$ values were observed for rudd. When the proportion of land use categories was considered and expressed in percentage to exempt from watershed size, there were a fish species effect and also a land use effect on fish $\delta^{15} \mathrm{~N}$ values (Table III). Factors affecting most the fish $\delta^{15} \mathrm{~N}$ values were the grassland area proportion then 


\section{Table III}

Analysis of variance on the parameters of model: $\delta^{15} \mathrm{~N}$ values function of fish species and land use variables in watersheds and buffer zones: $y=a x_{1}+b x_{2}+c x_{3}+d x_{4}+e x_{5}+f x_{6}+$ $g x_{7}+\varepsilon$ where $y$ is the response variable $\left(\delta^{15} N\right.$ values), $x_{1}$ is a factor (each level being fish species), $x_{2} \%$ grassland area, $x_{3} \%$ residential land, $x_{4} \%$ forest area, $x_{5} \%$ water area, $x_{6} \%$ camp sites, $x_{7} \%$ peat bog area and $\varepsilon$ the residuals.

\section{Tableau III}

Analyse de variance sur les paramètres du modèle : valeurs de $\delta^{15} \mathrm{~N}$ en fonction de l'espèce de poisson et des variables d'usage des sols dans les bassins versants et les zones tampon: $y=a x_{1}+b x_{2}+c x_{3}+$ $\mathrm{d} x_{4}+e x_{5}+f x_{6}+g x_{7}+\varepsilon$ où $y$ est la variable réponse (valeurs de $\delta^{15} \mathrm{~N}$ ), $x_{1}$ est un facteur espèce (chaque niveau étant une espèce de poisson), $x_{2} \%$ de surface en prairies, $x_{3} \%$ de zones résidentielles, $x_{4} \%$ de forêts, $x_{5} \%$ de surface en eaux, $x_{6} \%$ de campings, $x_{7} \%$ de tourbières et $\varepsilon$ un résidu.

\begin{tabular}{|l|c|c|c|c|c|c|}
\hline & \multicolumn{3}{|c|}{ Watershed scale } & \multicolumn{3}{c|}{ Buffer zone scale } \\
\hline & $\begin{array}{c}\text { Degrees of } \\
\text { freedom }\end{array}$ & F-values & $P$-values & $\begin{array}{c}\text { Degrees of } \\
\text { freedom }\end{array}$ & $F$-values & P-values \\
\hline Fish species & 403 & 3492.105 & $<0.0001$ & 403 & 351.7791 & $<0.0001$ \\
\hline Grassland & 4 & 620.289 & $<0.0001$ & 5 & 11.2697 & 0.0202 \\
\hline Forest & & & & 5 & 1.0073 & 0.3616 \\
\hline Residential land & 4 & 149.372 & 0.0003 & & & \\
\hline Water area & 4 & 3.935 & 0.1183 & & & \\
\hline Camp sites & 4 & 16.908 & 0.00147 & 5 & 43.3497 & 0.0012 \\
\hline Peat bog & 4 & 1.288 & 0.8252 & 5 & 5.7563 & 0.0617 \\
\hline
\end{tabular}

the residential land and the camp sites proportions in watershed (Figure 3a). Pooled as anthropogenic activities, the sum of these three parameters is well correlated with the fish community $\delta^{15} \mathrm{~N}$ values (Figure 4). On fish $\delta^{13} \mathrm{C}$ values, this land use effect wasn't observed (ANOVA, $n=417$, DF $=4, P=0.1623$ ).

For the buffer zone, the same effects were obtained, namely:

- When the area of land use categories was expressed in hectares, a fish species effect on the various $\delta^{15} \mathrm{~N}$ and $\delta^{13} \mathrm{C}$ values was emphasized (ANOVA, $n=417$; for $\delta^{15} \mathrm{~N}$ values, $\mathrm{DF}=403, P<0.0001$; for $\delta^{13} \mathrm{C}$ values, $\mathrm{DF}=403, P<0.0001$ ) but no effect of buffer zone size was observed (ANOVA, $n=417$; for $\delta^{15} \mathrm{~N}$ values, $\mathrm{DF}=4, P=0.0852$; for $\delta^{13} \mathrm{C}$ values, $\mathrm{DF}=4$, $P=0.3053$ ).

- When the land use categories were expressed in percentage, there were a fish species effect and a land use effect on fish $\delta^{15} \mathrm{~N}$ values (Table III) but only a fish species effect on fish $\delta^{13} \mathrm{C}$ values (ANOVA, $n=417, \mathrm{DF}=403, P<0.0001$ ). However, in this case, the variables affecting most the fish $\delta^{15} \mathrm{~N}$ values were respectively the camp sites proportion then the grassland area proportion with little difference; the residential land proportion not variable enough wasn't included in the model (Figure 3b). As seen for watershed land use, the buffer zone proportion affected by anthropogenic activities is well correlated with the fish community $\delta^{15} \mathrm{~N}$ values $\left(y=0.098 x+6.91, \mathrm{R}^{2}=0.9\right)$.

\section{DISCUSSION}

Many studies have used stable nitrogen and carbon isotope ratios to represent the trophic structure of aquatic systems and to indicate the trophic position of aquatic consumers (Peterson and Fry, 1987; Cabana and Rasmussen, 1994). The $\delta^{15} \mathrm{~N}$ value of a consumer depends on two main factors. It reflects first the lake $\delta^{15} \mathrm{~N}$ baseline value $\left(\delta^{15} \mathrm{~N}\right.$ of the primary 
a

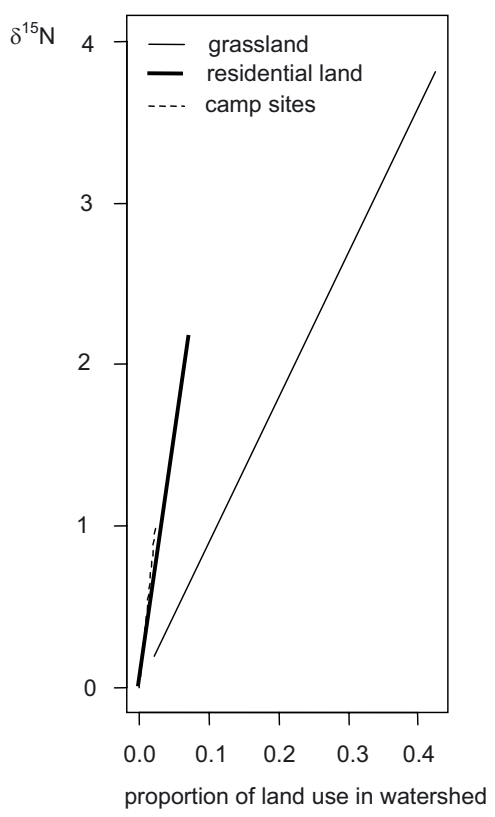

b

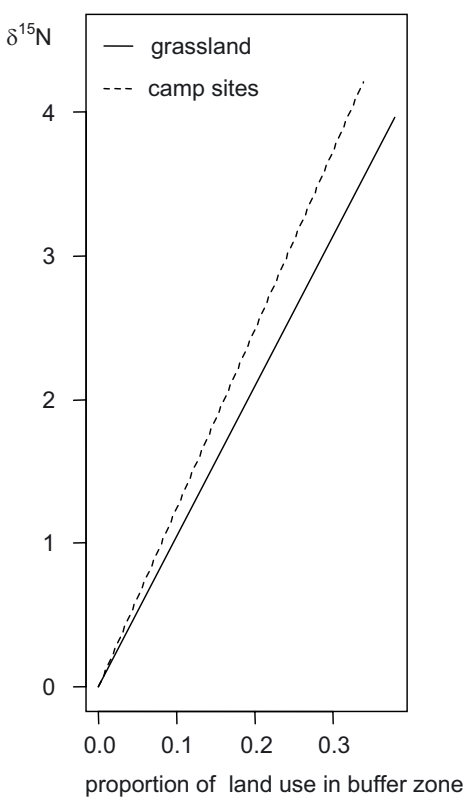

Figure 3

Relationships between fish $\delta^{15} \mathrm{~N}$ values and statistically significant descriptors of land use (a) in the watershed and (b) in the buffer zone.

\section{Figure 3}

Relations entre les valeurs de $\delta^{15} \mathrm{~N}$ des poissons et les descripteurs statistiquement significatifs de l'usage des sols (a) dans le bassin versant et (b) dans la zone tampon.

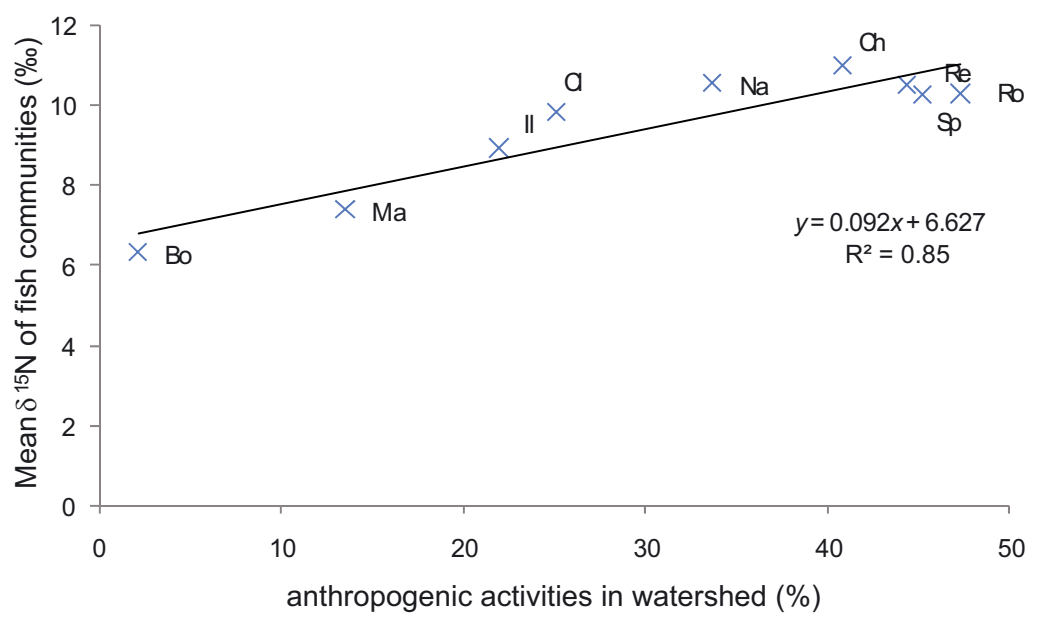

\section{Figure 4}

Relations between the fish community mean values $\delta^{15} \mathrm{~N}$ and the proportions of watersheds affected by anthropogenic activities for nine French Lakes (Bo: Bonlieu, Ch: Chalain, Cl: Clairvaux, Il: Ilay, Ma: Maclu, Na: Narlay, Re: Remoray, Ro: Les Rousses and Sp: Saint-Point).

\section{Figure 4}

Relations entre les valeurs moyennes $\delta^{15} \mathrm{~N}$ des communautés de poissons et les proportions des bassins versants impactées par les activités humaines dans neuf lacs français (Bo : Bonlieu, Ch: Chalain, Cl : Clairvaux, II : Ilay, Ma : Maclu, Na : Narlay, Re : Remoray, Ro : Les Rousses et Sp : SaintPoint). 
producers) which is influenced by the DIN $\delta^{15} \mathrm{~N}$ value and the preferential form of the assimilated inorganic nitrogen source, $\mathrm{NO}_{3}{ }^{-}\left(\delta^{15} \mathrm{~N}<10 \%\right.$ o or $\mathrm{NH}_{4}{ }^{+}\left(\delta^{15} \mathrm{~N} 20-30 \%\right.$ \%) (Syväranta et al., 2008). The $\delta^{15} \mathrm{~N}$ of a consumer also depends on its trophic level with an enrichment in ${ }^{15} \mathrm{~N}$ equal to $3.4 \% \pm 1.1$ for each trophic level (Post, 2002). The GLM showed both a fish species effect and a land use effect on the fish $\delta^{15} \mathrm{~N}$ values. The fish species effect could be explained by different trophic positions of the different species. Pike, which is a great predator in lakes (i.e. with a high trophic level), had the highest $\delta^{15} \mathrm{~N}$ values of all species except in lake Saint-Point. The comparison, between lakes, of the fish species position according to their mean $\delta^{15} \mathrm{~N}$ values underlined particular positions for various fish species in each lake. Concerning the land use effect the GLM showed that each category of anthropogenic activities occurring in the watershed and the buffer zone of our lakes significantly increased fish $\delta^{15} \mathrm{~N}$ values (Figures $3 \mathrm{a}$ and $3 \mathrm{~b}$ ). Two processes could be involved to explain the fish ${ }^{15} \mathrm{~N}$ enrichment with the increase of anthropogenic activities. First these activities led to increasing nutrient inputs in lakes with increasing primary production, hypolimnion anoxic conditions and $\mathrm{NH}_{4}{ }^{+}$production as results. After each overturn, ammonium primary assimilation in epilimnion could then lead to an increase in $\delta^{15} \mathrm{~N}$ of the whole lake food web including zooplankton (Syväranta et al., 2008) and fish which are long term integrators of temporal isotopic variation in $\delta^{15} \mathrm{~N}$ baseline. Because among the studied lakes, Lake Saint-Point and Lake Les Rousses showed both elevated oxygen saturation in deep zone (minimal values equal to $15 \%$ saturation and $88 \%$ saturation respectively, non published data), and the highest fish $\delta^{15} \mathrm{~N}$ values, an increase of $\mathrm{NH}_{4}{ }^{+}$assimilation did not seemed to be the major process implicated in the studied lakes. The second hypothesis is that all anthropogenic activities, in the studied watersheds and buffer zones, including agriculture which practice was accompanied by substantial manure spreading, led to human and livestock wastes inputs which have ${ }^{15} \mathrm{~N}$ enriched nitrate (Macko and Ostrom, 1994). In the studied lakes, the fish community $\delta^{15} \mathrm{~N}$ values variability would then reflect differences in DIN $\delta^{15} \mathrm{~N}$ values due to different inputs of ${ }^{15} \mathrm{~N}$ enriched nitrate. Among the three land use categories that constitute potential sources of nitrogen for the studied lakes, grassland seemed to be the major one at the watershed scale (Figure 3a) whereas at the buffer zone scale, camp sites and grassland have similar effects on $\delta^{15} \mathrm{~N}$ fish values (Figure $3 b$ ) suggesting their similar contributions to lake nitrogen inputs. Contrary to some previous studies in which agricultural activities were reported to be negatively correlated to consumer $\delta^{15} \mathrm{~N}$ values (McKinney et al., 1999) our results showed that both urban and agricultural activities led to an increase of the consumer $\delta^{15} \mathrm{~N}$ values. In these previous studies agricultural practices implied the use of synthetic fertilizers with low $\delta^{15} \mathrm{~N}$ values whereas in the watersheds we have studied only farmyard manure were used with high $\delta^{15} \mathrm{~N}$ values. Other studies have also demonstrated that an increase in lake nutrients inputs, whatever the form, led to an increase in consumer $\delta^{15} \mathrm{~N}$ values (Vander Zanden et al., 2005) following an enhancement of the denitrification process.

Our results are in agreement with those of Cabana and Rasmussen (1996) who linked elevated $\delta^{15} \mathrm{~N}$ values in primary consumers to increases in human population and to presumptive increases in wastewater inputs in the surrounding watersheds. They also agree with results from studies that demonstrated that $\delta^{15} \mathrm{~N}$ values of organisms (plants and animals) are useful indicators, as generalized measures, of incipient eutrophication in estuarine (McClelland et al., 1997; McClelland and Valiela, 1998; Cole et al., 2004) and lakes (Vander Zanden et al., op.cit.)

Concerning the fish $\delta^{13} \mathrm{C}$ values, the GLM showed a species effect but no land use effect. Because in the studied lakes, the correlation between fish $\delta^{15} \mathrm{~N}$ values and the global anthropogenic activity demonstrate that increasing anthropogenic pressure led to increasing lake nutrients or nitrogen inputs, one would be able to expect an increase in fish $\delta^{13} \mathrm{C}$ values with increasing anthropogenic activity in watersheds and buffer zones. In fact, it has been shown that, in great lakes, enhancement of primary production led to an increase in consumer $\delta^{13} \mathrm{C}$ values due to an increase of the dissolved atmospheric carbon in lake DIC (Perga and Gerdeaux, 2004). The same authors have also demonstrated that in small lakes, much more influenced by allochtonous organic matter inputs than great lakes, no correlation 
appeared between whitefish $\delta^{13} \mathrm{C}$ values and the lake trophic levels because respired DIC from allochthonous organic matter mineralization could supply the increase of carbon request instead of atmospheric carbon dissolution. In the present study, all lakes are small size lakes in which it has been shown that consumers, namely macroinvertebrates, have $\delta^{13} \mathrm{C}$ values largely influenced by organic matter recycling activity (Borderelle et al., 2008). In these lakes no correlation appeared between consumer $\delta^{13} \mathrm{C}$ values and anthropogenic activity because the organic matter that sustain the microbial activity could be allochthonous or autochtonous or both with different proportions between lakes.

The fish species effect on the fish $\delta^{13} \mathrm{C}$ values reflects the assimilation of different carbon sources. Whitefish with the lowest $\delta^{13} \mathrm{C}$ mean value feeds preferentially on pelagic zone a phytoplankton source of carbon whereas the other species are more benthic consumers. It is now well known that, with the same source of DIC phytoplankton has a lower fractionation than benthic primary producers (France, 1995; Gu et al., 1997; Sierszen et al., 2004).

The between lake variability of fish species positions according to their $\delta^{13} \mathrm{C}$ and $\delta^{15} \mathrm{~N}$ values could be due to the flexible and opportunistic feeding habits of many fish species (Vander Zanden et al., 1997) allowing a great variability of the fish species responses facing increasing nitrogen inputs (Table II). Roach and rudd present large ranges of values for both nitrogen and carbon (Figure 2). They are the most omnivorous of the fish species collected in our systems, taking up all the trophic niches according to the availability of feeding sources and being capable of consuming algae which proliferate when nutrients are in excess. Similarly, when watershed or buffer zone ${ }^{15} \mathrm{~N}$ enriched nitrate comes in a system, many plants and periphyton can proliferate. They have elevated $\delta^{15} \mathrm{~N}$ values and can be consumed by roach. This could explain the largest ranges of carbon and nitrogen ratios for these species. However, the General Linear Model results encourage considering the whole fish community in each lake, i.e. the whole fish community mean $\delta^{15} \mathrm{~N}$ values, as an indicator of land use.

The anthropogenic activities, as the sum of the camp sites, the grassland and the residential land proportions in the watersheds and in the buffer zones, are then well correlated with the fish community $\delta^{15} \mathrm{~N}$ values. Thus, the fish $\delta^{15} \mathrm{~N}$ values were useful to evaluate human and livestock wastes nitrogen inputs at both watershed-scale as well as at buffer zone-scale. Contrary to results of Lake et al. (2001), for our sites, the land use in the entire watershed had the same importance as in the buffer zones and, the watershed-scale data of land use were as useful as the land use data in buffer zones for predicting increases in $\delta^{15} \mathrm{~N}$ values for each site.

In summary, these results support the use of fish $\delta^{15} \mathrm{~N}$ values as indicators of anthropogenic activities in watersheds and in buffer zones and underline the impact of nitrogen inputs when they are principally made by human and livestock wastes in lakes.

\section{ACKNOWLEDGEMENTS}

This work has been supported by the Region of Franche-Comté and the Agence de l'Eau Rhône-Méditerranée (France).

\section{REFERENCES}

Aravena R., Evans M.L. and Cherry J.A., 1993. Stable isotopes of oxygen and nitrogen in source identification of nitrate from septic systems. Ground Water, 470, 180-186.

Borderelle A.L., Gilmette C., Lovy C., Gerdeaux D. and Verneaux V., 2008. Macroinvertebrate $\delta^{13} \mathrm{C}$ variability analysis for the assessment of lake trophic functioning. Fund. App. Lim., 172, 4, 289-300.

Cabana G. and Rasmussen J.B., 1994. Modelling food chain structure and contaminant bioaccumulation using stable nitrogen isotopes. Nature, 372, 255-257.

Cabana G. and Rasmussen J.B., 1996. Comparison of aquatic food chains using nitrogen isotopes. P. Natl. Acad. Sci. USA, 93, 10844-10847. 
Cole M.L., Valiela I., Kroeger K.D., Tomasky G.L., Cebrian J., Wigand C., McKinney R.A., Grady S.P. and Da Silva M.H.C., 2004. Assessment of a delta N-15 isotopic method to indicate anthropogenic eutrophication in aquatic ecosystems. J. Environ. Qual., 33, 124-132.

Ehleringer J.R., Bowling D.R., Flanagan L.B., Fessenden J., Helliker B., Martinelli L.A. and Ometto J.P., 2002. Stable isotopes and carbon cycle processes in forests and grasslands. Plant Biol., 4, 181-189.

France R.L., 1995. Carbon-13 enrichment in benthic compared to planktonic algae: Food web implications. Mar. Ecol. Prog. Ser., 124, 307-312.

France R.L., 2000. Comparing delta C-13 among littoral foodwebs using lake DOC. Aquat. Ecol., 34, 445-448.

Gormly J.R. and Spalding R.E., 1979. Sources and concentrations of nitrate-nitrogen in ground water of the central Platte region, Nebraska. Ground Water, 17, 291-301.

Gu B., Schelske C.L. and Brenner M., 1996. Relationship between sediment and plankton isotope ratios $(\delta 13 \mathrm{C}$ and $\delta 15 \mathrm{~N})$ and primary productivity in Florida lakes. Can. J. Fish. Aquat. Sci., 53, 875-883.

Gu B., Alexander V. and Schell D.M., 1997. Stable isotopes as indicators of carbon flows and trophic structure of the benthic food web in a subarctic lake. Arch. Hydrobiol., 138, 329-344.

Kreitler C.W., 1979. Nitrogen-isotope ratio study of soils and groundwater nitrate from alluvial fan aquifers in Texas. J. Hydrol., 42, 147-170.

Kreitler C.W., Ragone S. and Katz B.G., $1978 .{ }^{15} \mathrm{~N} /{ }^{14} \mathrm{~N}$ ratios of ground-water nitrate, Long Island, New York. Ground Water, 16, 404-409.

Lajtha K. and Marshall J.D., 1994. Sources of variations in the stable isotopic composition of plants. In: Lajtha K. and Michener J.D. (eds.), Stable Isotopes in Ecology, Blackwell Scientific, 45-62.

Lake J.L., McKinney R.A., Osterman F.A., Pruell R.J., Kiddon J., Ryba S.A. and Libby A.D., 2001. Stable nitrogen isotopes as indicators of anthropogenic activities in small freshwater systems. Can. J. Fish. Aquat. Sci., 58, 870-878.

Macko S.A. and Ostrom N.E., 1994. Pollution studies using stable isotopes. In: Lajtha K. and Michener J.D. (eds.), Stable Isotopes in Ecology, Blackwell Scientific, 45-62.

McClelland J.W. and Valiela I., 1998. Linking nitrogen in estuarine producers to land-derived sources. Limnol. Oceanogr., 43, 577-585.

McClelland J.W., Valiela I. and Michener R.H., 1997. Nitrogen-stable isotope signatures in estuarine food webs: A record of increasing urbanization in costal watersheds. Limnol. Oceanogr., 42, 930-937.

McKinney R.A., Lake J.L., Allen M. and Ryba S., 1999. Spatial variability in Mussels used to assess base level nitrogen isotope ratio in freshwater ecosystems. Hydrobiologia, 412, 17-24.

Perga M.E. and Gerdeaux D., 2004. Changes in $\delta^{13} \mathrm{C}$ of pelagic food webs: the influence of lake area and trophic status on the isotopic signature of whitefish (Coregonus lavaretus). Can. J. Fish. Aquat. Sci., 61, 1485-1492.

Peterson B.J. and Fry B., 1987. Stable isotopes in ecosystem studies. Ann. Rev. Ecol. Syst., 18, 293-320.

Ponsard S. and Arditi R., 2000. What can stable isotopes (delta N-15 and delta C-13) tell about the food web of soil macro-invertebrates? Ecology, 81, 852-864.

Post D.M., 2002. Using stable isotopes to estimate trophic position: models, methods, and assumptions. Ecology, 83, 703-718.

Post D.M., Pace M.L. and Hairston N.G., 2000. Ecosystem size determines food-chain length in lakes. Nature, 405, 1047-1049.

R Development Core Team (2006). R: A language and environment for statistical computing, R Foundation for Statistical Computing, Vienna, Austria, ISBN 3-900051-07-0, http://www.Rproject.org.

Schindler D.E. and Scheuerell M.D., 2002. Habitat coupling in lake ecosystems. Oikos, 98, 177-189.

Schindler D.E., Carpenter S., Cole J.J., Kitchell J.F. and Pace M.L., 1997. Influence of food web structure on carbon exchange between lakes and the atmosphere. Science, 277, 284-251.

Sierszen M.E., Mc Donald M.E. and Jensen D.A., 2003. Benthos as the basis for arctic lake food webs. Aquat. Ecol., 37, 437-445.

Syväranta J., Vesala S., Rask M., Ruuhijarvi J. and Jones R.I., 2008. Evaluating the utility of stable isotope analyses of archived freshwater sample materials. Hydrobiologia, 600, 121-130.

Vadeboncœur Y., Lodge D.M. and Carpenter S., 2001. Whole-lake fertilization effects on distribution of primary production between benthic and pelagic habitats. Ecology, 82, 4, 1065-1077.

Vander Zanden M.J., Cabana G. and Rasmussen J.B., 1997. Comparing trophic position of freshwater fish calculated using stable nitrogen isotope ratios $\left(\delta^{15} \mathrm{~N}\right)$ and literature dietary data. Can. J. Fish. Aquat. Sci., 54, 1142-1158.

Vander Zanden M.J., Vadeboncœur Y., Diebel M.W. and Jeppesen E., 2005. Primary consumer stable nitrogen isotones as indicators of nutrient source. Environ. Sci. Technol., 39, 7509-7515. 